\title{
Sosialisasi Dan Perencanaan Konsep Green Ruang Terbuka Hijau (RTH) Pada Pemukiman Kumuh Di Kelurahan Mario Kota Makassar
}

\author{
Sumarni Hamid Aly ${ }^{*}$, Mary Selintung, Muralia Hustim, Ibrahim Djamaluddin, Rasdiana \\ Zakaria, Nur An-nisa Putry \\ Departemen Teknik Lingkungan, Fakultas Teknik, Universitas Hasanuddin* \\ marni_hamidaly@yahoo.com*
}

\begin{abstract}
Abstrak
Meningkatnya kawasan kumuh perkotaan menimbulkan dampak adaptasi yang dilakukan oleh masyarakat terhadap konflik kemampuan dan kebutuhan akan hunian. Penanganan kawasan kumuh dengan menggusur penduduk seringkali memunculkan masalah baru yang sama peliknya, sehingga perlu dicari alternative penanganan dengan mengadakan Ruang Terbuka Hijau (RTH) skala Rumah Tangga (RT) dalam upaya meningkatkan kualitas hidup masyarakat dan lingkungan. Masalah permukiman kumuh di kota-kota besar seperti di Kota Makassar belum bisa diatasi dengan baik, salah satunya adalah masalah permukiman kumuh di di Kelurahan Mario Kecamatan Mariso Kota Makassar dimana kondisi kekumuhan yang ada merupakan kondisi berat. Konsep penanganan kumuh yang ada sekarang ini bukan hanya menghasilkan bangunan yang layak huni, tetapi adanya ruang terbuka hijau merupakan salah satu solusi penataan kawasan yang ada. Saat ini, ruang terbuka hijau bukan hanya sebagai penyediaan ruang terbuka yang ditanami vegetasi hijau tapi setidaknya memiliki konsep Ruang Terbuka Hijau Berkelanjutan atau dikenal dengan konsep Green RTH. Dalam hal ini, konsep yang dikenalkan pada warga sekitar adalah, raung terbuka hijau dimana di dalamnya terdapat saranapengolahan air limbah, komposter dan sumur resapan serta biopori. Sarana-sarana inilah yang natunya diharapkan dapat menangani secara tidak langsung permsalahan air bersih, air limbah dan permasalahan sampah yang selalu ada di kawasan kumuh. Maka dengan adanya Ruang Terbuka Hijau yang menerapakn beberapa konsep Green RTH yaitu green waste dan green water dapat meminimalisir kekumuhan di kawasan tersebut. Pada konsep green waste dibuat 3 komposter komunal yang tiap satu komposter memiliki volume 440 liter untuk menangani timbulan sampah 1235,775 liter/hari, sedangkan pada konsep green water dibuatkan Instalasi Pengolahan Air Limbah yang memiliki luas sebesar $302.8 \mathrm{~m} 2,1$ buah sumur resapan, 5 lubang resapan biopori dan 2 buah hidran.
\end{abstract}

Kata Kunci: Green RTH, Instalasi Pengolahan Air Limbah; Sumur Resapan; Biopori, Komposter.

\begin{abstract}
The increase in urban slum areas provokes the adaptation impact of the community towards the capability conflict and the need for shelter. Slums management by displacing residents often raises new problems that are equally complicated. Hence, another alternative treatment by maintaining household-scale green open space (RTH) to improve the quality of life of the community and the environment is necessary. The problem of slums in big cities, including in the city of Makassar has not been able to be overcome properly, one of which is the problem of slums in the Mario Sub-District, Mariso District, Makassar City where the conditions of the slums are a severe result. The concept of managing the existing slums is not only producing buildings that are habitable, but also providing green open space is one of the solutions in structuring the existing area. At present, green open space not only provides open space planted with green vegetation but has the concept of Sustainable Open Green Space or known as the Green RTH concept. In this case, the concept introduced to local residents is green open where available wastewater treatment, composter and infiltration wells and biopores. It is these facilities which are expected to be able to deal directly with the problems of clean air, wastewater and waste problems that are always present in slums. So with the presence of the "Sustainable" Green Open Space which explains the concept of Green RTH namely green waste and green water can minimize the slums in the region. In the concept of green waste, 3 communal composters are made, each composter has a volume of 440 liters for 1235.775 liters / day of waste generation, while in the concept of green water a Wastewater Treatment Plant has an area of $302.8 \mathrm{~m} 2,1$ infiltration well , 5 biopori infiltration holes and 2 hydrants.
\end{abstract}

Keywords: Sustainable Green Open Space, Wastewater treatment, infiltration well; biopori infiltration hole; composter. 


\section{Pendahuluan}

Kawasan permukiman adalah kawasan yang diperuntukan untuk tempat tinggal atau lingkungan hunian dan tempat kegiatan yang mendukung bagi peri kehidupan dan penghidupan. Di dalamnya terdapat kawasan perumahan yaitu kelompok rumah yang berfungsi sebagai lingkungan tempat tinggal atau lingkungan hunian yang dilengkapi dengan prasarana dan sarana lingkungan. Masalah permukiman kumuh hingga saat ini masih menjadi masalah utama yang dihadapi dikawasan permukiman perkotaan. Tingginya arus urbanisasi akibat menumpuknya sumber mata pencaharian dikawasan perkotaan menjadi magnet yang cukup kuat bagi masyarakat perdesaan (terutama golongan masyarakat berpenghasilan rendah) untuk bekerja di kawasan perkotaan dan tinggal dilahan-lahan ilegal yang mendekati pusat kota,hingga akhirnya menciptakan lingkungan permukiman kumuh. Menurut hasil pendataan oleh pemerintah Kota Makassar. Persebaran permukiman kumuh di Kota Makassar terdapat di 14 kecamatan. Yang termasuk dalam kategori kumuh berat terdapat pada kecamatan Tallo, Ujung Tanah, Rappocini, Mariso, dan Tamalate. Fasilitas pembuangan kotoran yang kurang memadai akan mengurangi manfaat potensial dari penyediaan air minum yang aman,sehingga kebersihan tidak terjamin. Hal tersebut dapat menimbulkan berbgai penyakit di masyarakat misalnya: penyakit kulit dan diare. Tingkat pelayanan sanitasi yang ada di kelurahan mario berada dibawah $75 \%$. Sehingga masih ada masyarakat di Kelurahan Mario tersebut yang belum memiliki MCK yang umum yang memadai, layak dan sehat. Kemiskinan adalah salah satu penyebab utama ketidak layakan sarana sanitasi mereka,hal lain yang menyebakan adalah kurangnya kesadaran masyarakat untuk mengolah limbah cair rumah tangganya ke tangga septic, kurangnya pmahaman tentang sanitasi dan kesehatan, serta adanya keterbatasan dana untuk membangun Jamban dirumah masing masing, sehingga solusi lain yang ditawarkan adalah merehabilitasi MCK umum yang telah ada di kelurahan Mario tersebut. Saat ini di kelurahan Mario terdapat RTH Rukun Warga (RW) dapat dimana fasilitas yang disediakan berupa lapangan untuk berbagai kegiatan, baik olahraga maupun aktivitas lainnya, beberapa unit bangku taman yang dipasang secara berkelompok sebagai sarana berkomunikasi dan bersosialisasi antar warga namun kondisi fasilitas yang ada terbilang sangat sederhana dan RTH tersebut belum berfungsi optimal sebagai RTH. Hal ini dapat dilihat belum tersedianya vegetasi yang memenuhi kriteri yang ada sehingga fungsi RTH sebagai resapn air belum optimal. Solusinya berupa pembuatan konsep Green dalam hal ini yakni RTH yang ada telah menyediakan fasilitas-fasilitas yang ada seperti: 1) Green waste, yakni tersedianya sarana pemilahan dan pengolahan sampah organik, 2) Green waste water, yakni terdapat fasilitas pengolahan air limbah skala komunal untuk menghasilkan kembali air yang dapat dipakai dalam penyiraman tanaman dan sebagai hydrant pencegah kebakaran, 3) Green Energy, yakni lampu taman yang digunakan tidak lagi menggunakan listri tetapi telah memanfaatkan energi panas matahari, 4) Green Community, yakni terdapat fasilitas untuk kegiatan komunitas masyarakat setempat dan 5) Green Building yakni menggunakan bahan bangunan yang ramah lingkungan. Dengan demikian, RTH yang dihasilkan nantinya berupa konsep Green RTH skala RW di Kelurahan Mario. Permasalahan yang dihadapi dikelurahan Mario saat ini adalah banyaknya permasalahan kemiskinan dan permukiman kumuh antara lain indikator permasalahannya adalah masih adanya masyarakat yang belum memiliki jamban keluarga di rumah masing masing, dan beberapa MCK umum yang tidak tertata rapi dan rusak. Kondisi real yang ada di kelurahan Mario tersebut adalah: 1). Masih adanya MCK umum yang tidak layak pakai untuk masyarakat Kelurahan Mario, 2). Ada bangunan hunian pada lokasi permukiman tidak memiliki kloset (Leher Angsa) yang terhubung dengan tangki septik, 3). 100\% saluran Pembuangan Air Limbah 
Rumah Tangga tercampur dengan Drainase Lingkungan, 4). Kesadaran masyarakat akan pentingnya sanitasi lingkungan melalui MCK umum masih kurang, dan 5).RTH yang berupa open space saja dimana tidak tersedia vegetasi yang sesuai kriteria RTH. Dengan perkenalan dan pembuatan Konsep Green RTH di kawasan kumuh Kelurahan Mario, tepatnya di Jalan Baji Dakka I maka akan dapat menyelesaikan permsalahan sanitasi di kawasan tersebut dan menghasilkan RTH yang berkelanjutan.

\section{Penataan Kawasan Kumuh Dengan Penerapan Konsep “Green" RTH}

Pemukiman kumuh adalah permukiman yang tidak layak huni karena ketidakteraturan bangunan, tingkat kepadatan bangunan yang tinggi, dan kualitas bangunan serta sarana dan prasarana yang tidak memenuhi syarat. Perumahan kumuh adalah perumahan yang mengalami penurunan kualitas fungsi sebagai tempat hunian (UU No.1 tahun 2011).Kumuh merupakan kesan atau gambaran secara umum tentang sikap dan tingkah laku yang rendah di lihat dari standar hidup dan penghasilan kelas menengah. Dengan kata lain, kumuh dapat di artikan sebagai tanda atau cap yang diberikan golongan atas yang sudah mapan kepada golongan bawah yang belum mapan. Kawasan kumuh meskipun tidak dikehendaki namun harus diakui bahwa keberadaanya dalam perkembangan wilayah dan kota tidak dapat dihindari. Kumuh dalam kamus tata ruang berarti juga mengadung sifat-sifat keusangan yang banyak di tunjukan kepada keadaan guna lahan atau zona atau kawasan yang sudah sulit diperbaiki lagi, jadi yang lebih baik di bongkar tapi juga dapat ditunjukan kepada keadaan yang secara fisik masih cukup baik, belum tua, tapi sudah tidak lagi memenuhi sebagai standar kelayakan. (Jeskson, dkk 2018).

\subsection{Ruang Terbuka Hijau}

Ruang terbuka hijau (RTH) merupakan bagian ruang terbuka (open spaces). Betapa luasnya cakupan ruang terbuka ini, maka yang akan dibahas adalah ruang terbuka di kawasan perkotaan. Berbagai referensi menyatakan bahwa ruang terbuka adalah daerah atau tempat terbuka di lingkungan perkotaan. Ruang terbuka berbeda dengan istilah ruang luar (exterior space), yang ada di sekitar bangunan dan merupakan kebalikan ruang dalam (interior space) di dalam bangunan. Ruang terbuka yang disebut Taman Kota (park), yang berada di luar atau diantara beberapa bangunan di lingkungan perkotaan, semula dimaksudkan pula sebagai halaman atau ruang luar, yang kemudian berkembang menjadi istilah Ruang Terbuka Hijau (RTH) kota, karena umumnya berupa ruang terbuka yang sengaja ditanami pepohonan maupun tanaman, sebagai penutup permukaan tanah. Tanaman produktif berupa pohon berbuah dan tanaman sayuran pun kini hadir sebagai bagian dari RTH berupa lahan pertanian kota atau lahan perhutanan kota yang amat penting bagi pemeliharaan fungsi keseimbangan ekologis kota. Ruang terbuka harus ditanami tetumbuhan, atau hanya sedikit terdapat tetumbuhan, namun mampu berfungsi sebagai unsur ventilasi kota, seperti plaza dan alun-alun.

Peraturan Menteri Dalam Negeri No. 1 Tahun 2007 tentang Ruang Terbuka Hijau Kawasan Perkotaan, memilki beberapa definisi terkait RTH yakni:

a. Ruang terbuka adalah ruang-ruang dalam kota atau wilayah yang Iebih luas baik dalam bentuk area/ kawasan maupun dalam bentuk area memanjang jalur di mana dalam penggunaannya lebih bersifat terbuka yang pada dasarnya tanpa bangunan.

b. Ruang Terbuka Hijau Kawasan Perkotaan yang selanjutnya disingkat RTHKP adalah bagian dari ruang terbuka suatu kawasan perkotaan yang diisi oleh tumbuhan dan tanaman guna mendukung manfaat ekologi, sosial, budaya, ekonomi dan estetika. 
Pada Undang-Undang No. 26 Tahun 2007, didefinisikan bahwa ruang terbuka hijau adalah area memanjang/ jalur atau mengelompok, yang penggunaannya lebih bersifat terbuka, tempat tumbuh tanaman, baik yang tumbuh secara alamiah maupun yang sengaja ditanam.

\subsection{Tujuan Ruang Terbuka Hijau}

Tujuan ruang terbuka hijau menurut berbagai sumber yang ada, baik dari referensi buku, peraturan perundangan, dirjen PU atau Permendagri. Untuk lebih jelasnya dapat dipaparkan sebagai berikut :

Menurut Permendagri No. 1 tahun 2007 Tentang penataan Ruang Terbuka Hijau Kawasan Perkotaan tujuan dari pembentukan ruang terbuka hijau adalah sebagai berikut :

a. Menjaga keserasian dan keseimbangan ekossitem lingkungan perkotaan.

b. Mewujudkan keseimbangan antara lingkungan alam dan lingkungan buatan di perkotaan, dan

c. Meningkatkan kualitas lingkungan perkotaan yang sehat, indah, bersih, dan nyaman.

Menurut Direktorat Jendral Penataan Ruang Departement Pekerjaan Umum, 2008 menunjukan bahwa tujuan pembentukan ruang terbuka hijau adalah :

1. Keindahan (tajuk, tegakan, pengarah, pengaman, pengisi, dan pengalas), mengurangi pencemaran udara, peredam kebisingan, memperbaiki iklim mikro, penyangga system kehidupan dan kenyamanan.

2. Perlindungan, pencegah erosi dan penahan badai

3. Pendidikan, kesenangan, kesehatan, interaksi social

4. Pendukung ekosistem makro, vebtilasi dan pemersatu ruang kota

5. Kenyamanan spasial, visual, audial, dan termal serta nilai ekonomi

6. Pelayanan masyarakat dan penyangga lingkungan kota, wisata alam, produksi hasil hutan

7. Keseimbangan ekosistem

8. Reservasi dan perlindungan situs bersejarah

\subsection{Program Pengembangan Kota Hijau}

Program Pengembangan Kota Hijau (P2KH) adalah upaya untuk kota yang berkelanjutan dengan rencana Tata Ruang Wilayah (RTRW) Kota / Kabupaten dalam kerangka mewujudkan atribut kota hijau yaitu: 1). Perencanaan dan perancangan kota yang ramah Lingkungan, 2). Membahas ruang terbuka hijau, 3). Konsumsi energi yang efisien, 4).Pengelolaan air yang efektif, 5). Pengelolaan limbah dengan prinsip 4R, 6). Bangunan hemat energy, 7). Penerapan sistem transportasi yang berkelanjutan; dan 8). Peningkatan peran masyarakat sebagai komunitas hijau.

Terkait atribut kota hijau yang dimaksud dalam program pengembangan kota hijau yaitu:

1. Green planning and design: Perencanaan dan perancangan yang ramah lingkungan

2. Green open space : Peningkatan kualitas RTH sesuai karakteristik kota dengan target RTH public $30 \%$

3. Green waste : Upaya untuk nol limbah dengan menerapkan prinsip 4R yaitu mengurangi sampah, mengembangkan proses daur ulang, meningkatkan nilai tambah dan menggunakan kembali.

4. Green transportation : Sistem Pengembangan transportasi yang berkelanjutan, missal transportasi umum, jalur sepeda dan jalur pejalan kaki. 
5. Green water :Efisiensi pemanfaatan sumber daya udara, mencegahi pencemaran dan pengendalian risiko Energi Hijau yang terkait dengan air.

6. Green building : Bangunan hemat energi diawali perda bangunan daerah

7. Green energy : Menggunakan sumber energi yang ramah lingkungan

8. Green community : Kepekaan, kepedulian, dan peran serta masyarakat aktif dalam pengembangan atribut-atribut kota hijau.

\subsection{Profil Kekumuhan Kelurahan Mario}

Kelurahan Mario merupakan salah satu kelurahan yang terletak di kecamatan Mariso Kota Makassar Provinsi Sulawesi Selatan yang terdiri dari 5 RW dan 15 RT.

\subsubsection{Faktor Geografis}

Wilayah Kelurahan Mario Kecamatan Mariso Kota Makassar umumnya adalah wilayah perkotaan sehingga keterjangkauan sarana infrastruktur seperti transportasi, listrik, sumber air, media komunikasi, irigasi, pengelolaan sampah dan sebagainya cukup merata namun kurang maksimal kesemua wilayah dalam kelurahan. Mario. Dengan kondisi geografis demikian maka keterjangkauan wilayah-wilayah di tingkat RW/RT sangat lancar. Namun dari pandangan lain hal tersebut mengakibatkan semakin tingginya ego sosial masyarakat dalam membangun kepedulian bersama.

\subsubsection{Faktor Demografi}

Pola persebaran penduduk Kelurahan Mario Kecamatan Mariso Kota Makassar umumnya sangat padat mengingat Kelurahan Mario berada dalam wilayah perkotaan dalam Kecamatan Mariso yang dikenal dengan wilayah perdagangan, juga tempat hunian warga begitu rapat sehingga mengakibatkan tingginnya kedinamisan dan persoalan-persoalan yang menyangkut pola hidup bertetangga, di lain sisi karena kepadatan tersebut mengakibatkan tingginya persaingan hidup yang lambat laung mengakibatkan kecemburuan sosial.

\subsubsection{Faktor Sumber Daya Manusia}

Kelurahan Mario Kecamatan Mariso adalah wilayah perkotaan maka Sumber Daya manusianya juga cukup banyak, namun apabila ditelusuri secara teliti maka mereka itu sebagian besar adalah pendatang dari luar kelurahan atau dari luar kota, yang domisilinya karena tempat kerja berada dalam wilayah Kelurahan Mario Ada beberapa masyarakat asli yang mempunyai tingkat keterampilan cukup atau intelektual yang cakap namun mereka kebanyakan keluar kelurahan, sehingga mereka yang tinggal dalam wilayah hanyalah meraka yang mempunyai kualitas yang kurang, keterampilan sangat terbatas sehingga berimplikasi pada perilaku kurang disiplin serta pola pikir yang sempit dalam mengembangkan mata pencaharian dan meningkatkan pendapatannya yang masih menerapkan sistem ekonomi konvensional yang cenderung subsisten memenuhi kebutuhan domestik.

\subsubsection{Faktor Sumberdaya Alam}

Karena wilayah Kelurahan Mario Kecamatan Mariso adalah perkotaan dengan hunian warga begitu rapat dan kepadatan penduduk yang tinggi maka secara umum potensi sumber daya alam Kelurahan Mario Kecamatan Mariso Kota Makassar tidak mencukupi mengingat struktur tanah dan lahan kosong sudah berubah menjadi tempat hunian dan usaha perekonomian (lost, ruko, 
dll).

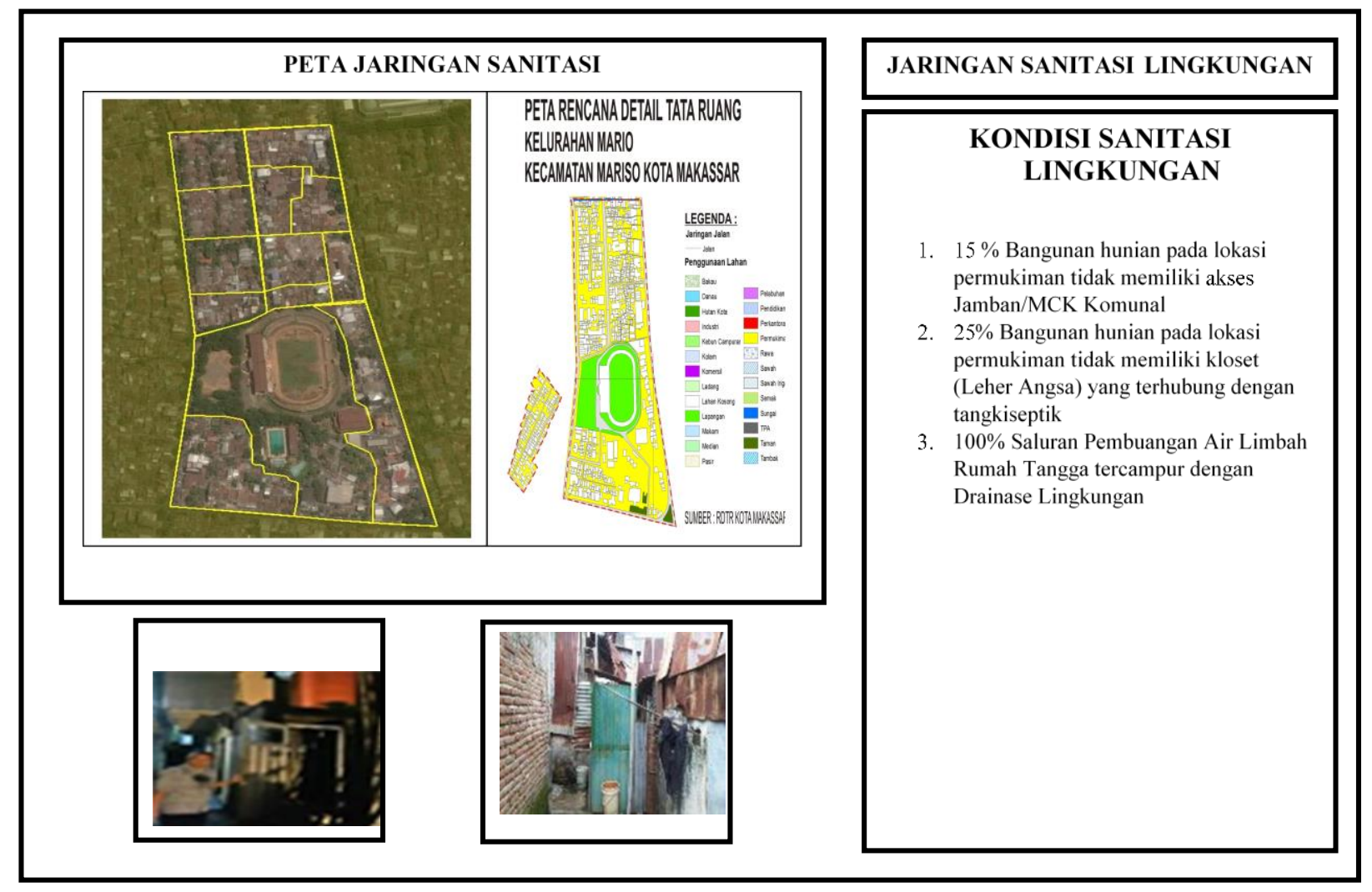

Gambar 1. Profil Kekumuhan Kelurahan Mario

\section{Metode Untuk Menangani Permasalahan}

Berdasarkan permasalahan yang ada, maka secara umum solusi yang diharapkan dapat mengatasi permasalahan yang ada. Berikut adalah solusi yang ditawarkan dalam mengatasi permasalahan mitra, yakni:

- Menawarkan Konsep Green dalam hal ini yakni RTH yang ada telah menyediakan fasilitasfasilitas yang ada seperti: 1) Green waste, yakni tersedianya sarana pemilahan dan pengolahan sampah organic, 2) Green wastewater, yakni terdapat fasilitas pengolahan air limbah skala komunal untuk menghasilkan kembali air yang dapat dipakai dalam penyiraman tanaman dan sebagai hydrant pencegah kebakaran, 3) Green Energy, yakni lampu taman yang digunakan tidak lagi menggunakan listri tetapi telah memanfaatkan energi panas matahari, 4) Green Community, yakni terdapat fasilitas untuk kegiatan komunitas masyarakat setempat dan 5) Green Building yakni menggunakan bahan bangunan yang ramah lingkungan.

- Dengan adanya konsep Green RTH yang dibuatkan maka dalam RTH akan terdapat sarana MCK plus IPAL dan septik tank skala komunal sehingga secara tidak langsung permasalahan air limbah di Kelurahan Mario dapat teratasi. Air hasil pengolahan limbah dapat digunakan dalam penyiraman vegetasi di RTH dan sebagai hydrant mengingat kawasan tersebut merupakan hunia yang padat sehingga rawan terjadi kebakaran.

- Dalam konsep Green RTH, pengolahan sampah organik dilakukan menggunakan komposter dan biopori. Dengan biopori proses pembusukan sampah daun lebih cepat dan proses infiltrasi pun akan optimal. Dengan demikian RTH pun bisa berfungsi sebagaimana mestinya. 
Dalam Program pengabdian ini, sosialisasi dilakukan pada masyarakat tetang pentingnya suatu RTH pada tiap kawasan. Di kampong Mario telah memiliki suatu kelembagaan yang melaksanakan berbagai program sanitasi dari pemerintah sehingga koordinasi antara pelaksana dan mitra lebih terpadu. Sosialisasi yang dilakukan berupa penyuluhan tentang RTH dan Konsep Green RTH. Dalam sosialisasi akan dikemukakan konsep Green RTH pada lokasi RTH yang telah ditentukan.

\subsection{Perencanaan Konsep "Green” Ruang Terbuka Hijau}

\subsubsection{Instalasi Pengolahan Air Limbah}

Instalasi Pengolahan Air Limbah (IPAL) Komunal merupakan sistem pengolahan air limbah yang dilakukan secara terpusat yaitu terdapat bangunan yang digunakan untuk memproses limbah cair domestik yang difungsikan secara komunal agar lebih aman pada saat dibuang ke lingkungan, sesuai dengan baku mutu lingkungan.

a. Konsep Desain Instalasi Pengolahan Air Limbah

Untuk mengetahui debit perencanaan air limbah didapatkan melalui persamaan berikut :

Debit $=$ jumlah penduduk $\mathrm{x}$ kebutuhan air bersih $\mathrm{x} 80 \%$ air limbah

Berdasarkan data Badan Pusat Statistik Kota Makassar,2018 Jumlah penduduk pada RT 3 RW 2 yaitu 390 orang. Debit perencanaan diketahui untuk dibuatnya instalasi pengolahan air limbah (IPAL) sehingga dapat diketahui dimensi IPAL yang akan dibuat. Desain bangunan utama IPAL biofilter yang direncanankan adalah sebagai berikut :

1) Bak equalisasi/ Bak pengumpul terbuat dari pasangan batu bata, bentuk persegi Panjang dilengkapu dengan bar screen berupa kawat yang terbuat dari stainlies. Untuk volume bak diketahui dengan persamaan berikut :

Volume bak $=\frac{\text { lama waktu tinggal }(\text { menit }) \text { debit perencanaan }(\mathrm{m} 3 / \mathrm{hari})}{24 \mathrm{jam}}$

Dari persamaan di atas dapat diketahui dimensi bak yang akan dibuat atau direncanakan.

2) Bak sedimentasi/ Bak pengendapan awal terbuat dari pasangan batu bata dan tertutup yang dilengkapi dengan lubang control, bak berbentuk persegi Panjang, air limbah masuk melalui pipa inlet secara gravitasi, pemeliharaan dengan cara penguasan manual. Kriteria perencanaan menurut standar JJWA dalam Said (2006) adalah :

- Waktu tinggal (Retention time) rata-rata $=3-5$ jam

- Beban permukaan (surface loading) $=20-50 \mathrm{~m}^{3} / \mathrm{m}^{2} / \mathrm{hari}$

3) Reaktor Biofilter Anaerob, reactor ini dipasang secara seri terhadap reactor biofilter aerob, dengan bahan pasangan batu bata berbentuk persegi Panjang tertutup, media filter yang digunakan batu apung berbentuk persegi Panjang tertutup, media filter yang digunakan batu apung dan kerikil/pecahan batu kali dengan diameter 2-3 cm, fluida/ air limbah dialirkan secara down flow dan updlow. Kriteria perencanaan menurut standar JWWA dalam Said (2006) adalah :

- Waktu tinggal total rata-rata $=6-8$ jam

- $\quad$ Tinggi ruang lunpur =0,4 m

- $\quad$ Tinggi media pembiakan mikroba =0,9-1,5 $\mathrm{m}$

- Tinggi air di atas bed media $=0,2 \mathrm{~m}$

- Beban BOD per volume media $=0,4-4,7 \mathrm{~kg}$ BOD $/ \mathrm{m} / \mathrm{hari}$ 
- Beban BOD per satuan permukaan media $(\mathrm{La})=5-30 \mathrm{~g} \mathrm{BOD} / \mathrm{m} / \mathrm{hari}$.

Menurut BPPT, bak biofilter anaerob efisiensi untuk pengurangan BOD

mencapai $80 \%$. Untuk bak biofilter volume media yaitu berjumlah $60 \%$ dari total volume reactor dan dibagi menjadi dua bagian. Beban BOD di dalam air limbah dapat diketahui dari persamaan beikut:

Beban BOD air limbah = Debit air limbah $\left(\mathrm{m}^{3} /\right.$ hari $) \times$ BOD influent $(\mathrm{g} / \mathrm{m} 3)$

Volume media yang diperlukan diketahui pada persamaan berikut :

Volume media yang diperlukan $=\frac{\text { beban BOD air limbah }(\mathrm{kg} / \mathrm{hari})}{\text { beban BOD yang ditetapkan }\left(\frac{\mathrm{kg}}{\mathrm{m}} / \mathrm{hari}\right)}$

Volume reactor yang diperlukan dapat diketahuo pada persamaan beikut :

Volume reactor $=60 \% \mathrm{x}$ volume media $\left(\mathrm{m}^{3}\right)$

Waktu tinggal dalam bak biofilter anaerob ditentukan pada persamaan berikut :

Waktu tinggal $=\frac{\text { volume reaktor } \text { yang diperlukan }(m 3)}{\text { debit }(m 3 / \text { hari })} \times 24 \mathrm{jam} / \mathrm{hari}$

Dari persamaan diatas dapat diketahui volume reactor yang akan dibuat dan juga dimensi reactor yang diperlukan, begitu pula wwaktu tinggal yang di perlukan selama dalam bak biofilter anaerob.

4) Kebutuhan oksigen

Kebutuhan oksigen di dalam reactor biofilter aerob sebanding dengan jumlah BOD yang dihilangkan. Aerasi dilakukan dengan menghembuskan udara dari blower melalui Perforated Pipe diffuser yang dipasang di dalam air dengan buka - tutup secara otomatis. Jika suplai udara dihentikan maka diffuser akan tertutup secara otomatis (Siregar, 2005).

5) Bak Pengendap Akhir

Bak pengendap akhir terbuat dari pasangan bata dan tertutup dilengkapi lubang control, bentuk bak persegi Panjang dengan pipa inlet dan outlet secara gravitasi. Bak ini berfungsi sebagai pengendap akhir sesuai kebutuhan dan air limpasan masuk ke bak khlorinator. Kriteria perencanaan menurut standar JWWA dalam Said, (2006) adalah :

- Waktu tinggal (Retention time) rata-rata $=2-5$ jam

- Beban permukaan (surface loading) $=20-50 \mathrm{~m} / \mathrm{hari}$

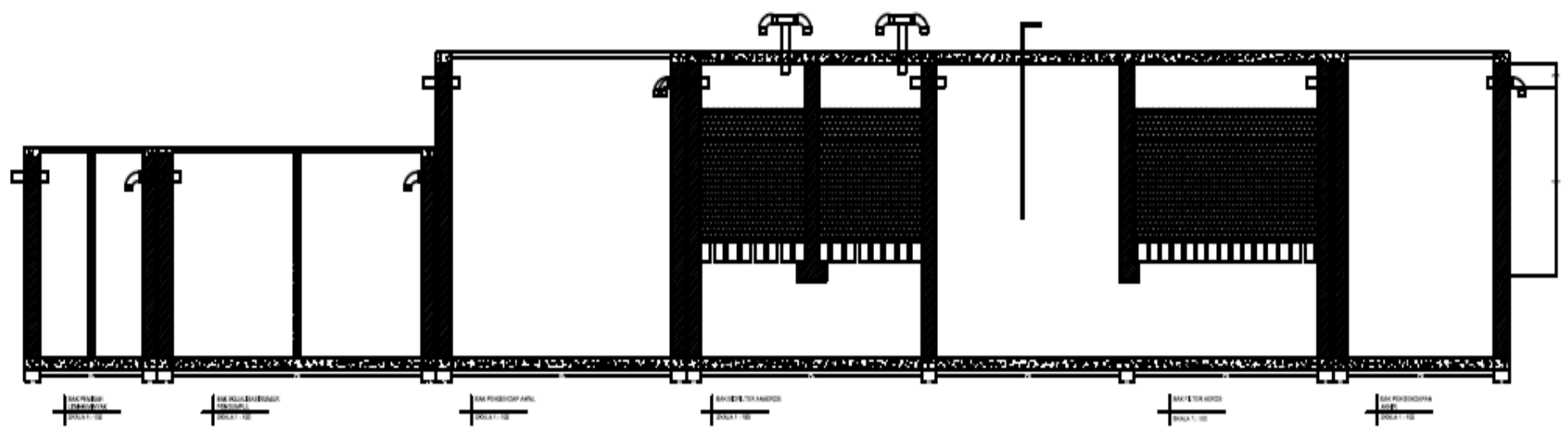

Gambar 2. Desain IPAL 
Tabel 1. Dimensi IPAL yang ada pada RTH

\begin{tabular}{|c|c|c|c|c|c|c|c|}
\hline \multirow[t]{2}{*}{ No } & \multirow{2}{*}{ Nama Bak } & volume yang diperlukan & $\mathbf{P}$ & $\mathbf{L}$ & $\mathbf{T}$ & $\begin{array}{c}\text { Free } \\
\text { board }\end{array}$ & $\begin{array}{c}\text { Vol. } \\
\text { Efektif }\end{array}$ \\
\hline & & (m3) & (m) & (m) & (m) & (m) & (m3) \\
\hline 1 & $\begin{array}{l}\text { Bak Pemisah } \\
\text { Lemak/Minyak }\end{array}$ & 5.41 & 1.4 & 2 & 2 & 0.25 & 5.41 \\
\hline 2 & Bak Equalisasi & 27.08 & 3.4 & 4 & 2 & 0.25 & 27.08 \\
\hline 3 & Bak Pengendapan Awal & 22.66 & 3 & 2.4 & 3 & 0.25 & 22.66 \\
\hline 4 & Bak Biofilter Anaerob & 48.75 & 3 & 2.8 & 3 & 0.25 & 48.75 \\
\hline 5 & Bak Biofilter Aerob & 29.25 & & & & & 29.25 \\
\hline & a. Ruang Aerasi & & 2.5 & 2 & 3 & 0.25 & \\
\hline & b. Ruang Bed Media & & 2.5 & 2 & 3 & 0.25 & \\
\hline 6 & Bak Pengendapan Akhir & 10.83 & 2 & 1.8 & 3 & 0.25 & 10.83 \\
\hline & Total & 143.98 & 17.8 & 17 & & & \\
\hline
\end{tabular}

\subsubsection{Green Waste Dengan Menggunakan Komposter}

Konsep green waste ini dilakukan karena tidak adanya pengolahan sampah di Kelurahan Mario. Hal ini menyebabkan tercemarnya lingkungan dikarenakan sampah yang dibuang langsung ke lingkungan serta tidak adanya pengolahan limbah terlebih dahulu. Dengan adanya green waste ini masyarakat dapat memanfaatkan sampah organik dapur yang dihasilkan dari kegiatan rumah tangga. Dalam penerapan komposter berdasarkan SNI 19-7029-2004 mengenai Spesifikasi komposter rumah tangga. Dari hasil suvey timbulan sampah bersama BKM didapatkan 1235,775 liter per hari untuk volume sampah organik. Untuk pembuatan satu unit komposter dibutuhkan 440 liter, sehingga untuk pembuatan komposter dengan volume 1235,775 liter dibagi dengan volume komposter 440 liter menghasilkan tiga komposter. Berikut desain komposter

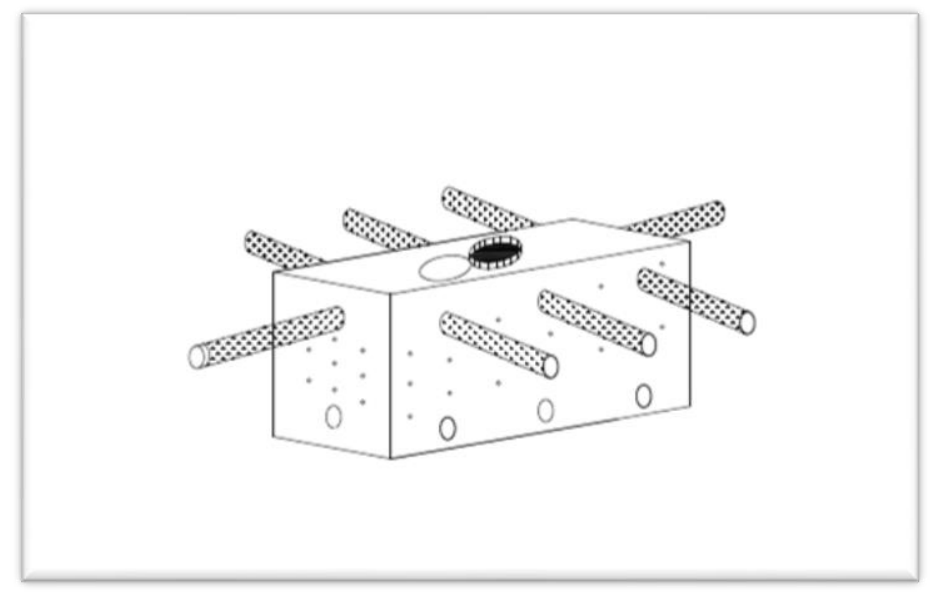

Gambar 3. Desain Komposter

\subsubsection{Perencanaan Sumur Resapan}

Sistem resapan buatan ini dapat menampung air hujan melalui aliran permukaan yang tidak terserap oleh permukaan tanah, dapat berbentuk sumur, kolam resapan, saluran porous (berpori), dan sejenisnya. Jumlah sumur resapan yang digunakan adalah satu (1) sumur resapan. 

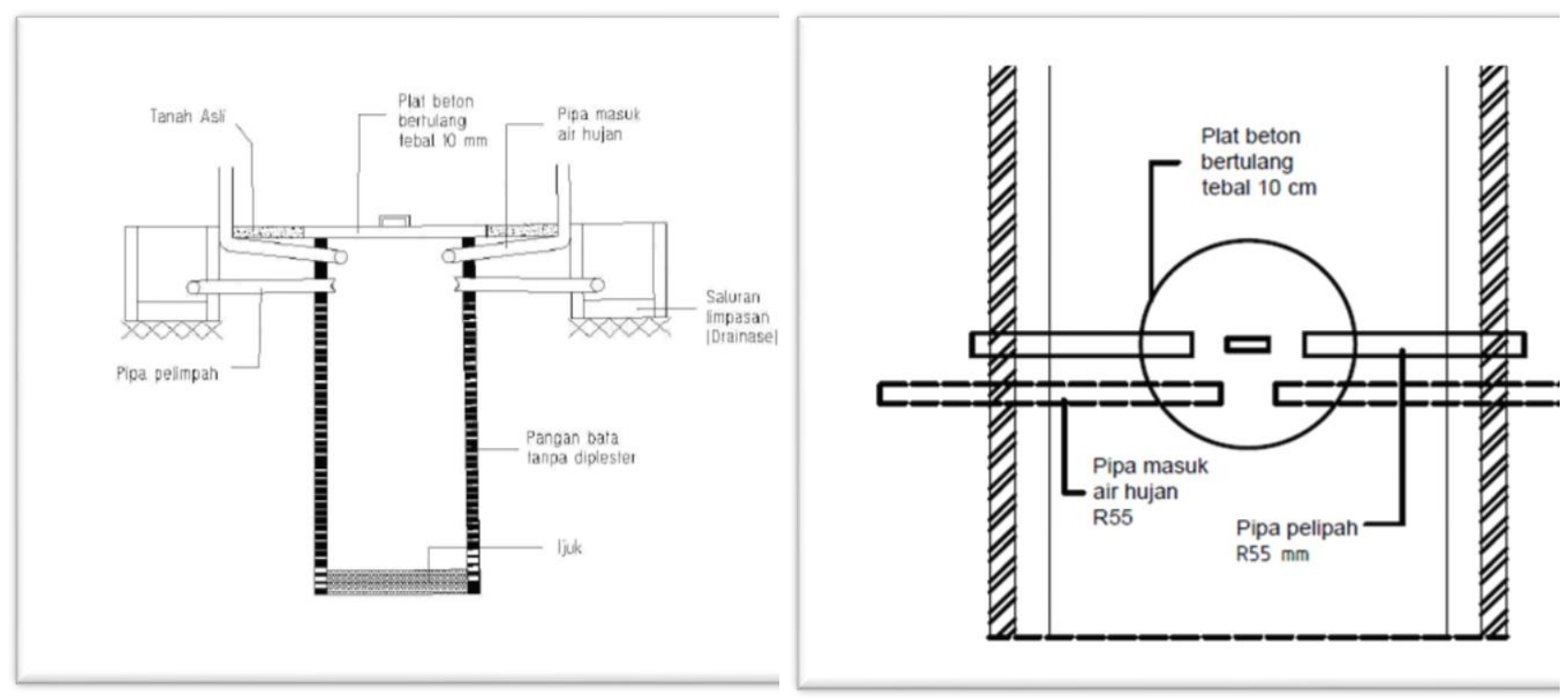

Gambar 4. Konsep Sumur Resapan pada RTH

\subsubsection{Lubang Biopori}

Jumlah lubang resapan biopori untuk perenanaan RTH adalah 5 lubang, kemudian diperhitungkan luas area atau luas RTH untuk membuat lubang resapan sebanyak 5 lubang tersebut. Jika diasumsikan dalam $100 \mathrm{~m} 2$ tanah, idealnya dapat dibuat lubang resapan biopori dengan diameter $10 \mathrm{~cm}$ sebanyak 50 lubang maka perhitungannya adalah jumlah lubang resapan biopori dibagi 50 buah dan dikali 100 (m2). Dengan demikian, untuk membuat lubang resapan biopori sebanyak 5 buah dibutuhkan luas area atau ruang terbuka hijau sebesar $10 \mathrm{~m}^{2}$. Untuk perencanaan lokasi pembuatan lubang resapan biopori ditempatkan di sekeliling pohon ini dapat menciptkan suatu siklus hara yang baik sehingga kesuburan tanah dapat dipertahankan dan kebutuhan pupuk kimiawi dapat dikurangi.

\subsubsection{Perencanaan Hidran}

Kondisi eksisting karakteristik hunian di Kelurahan Mario ini memiliki tingkat kepadatan yang tinggi dengan jarak bangunan saling berdekatan. Tingginya tingkat kepadatan penduduk dan saling berdekatan maka ada potensi terjadi kebakaran sehingga dibutuhkan hidran yang berfungsi untuk memadamkan api. Dalam perencanaan sistem pemadam kebakaran hidran pada bangunan ini, perlu memperhatikan beberapa faktor penting seperti klasifikasi bangunan,pasokan air untuk hidran halaman adalah 2400 liter/menit waktu mampu mengalirkan air minimal adalah 45 menit. Untuk perlindungan bagian luar bangunan di pasang kotak hidran halaman dengan jangkauan semburan air dari selang Panjang maksimum adalah $45 \mathrm{~m}(30 \mathrm{~m}+15 \mathrm{~m})$. selain itu juga dipasang sambungan ke IPAL yang ada pada Ruang Terbuka Hijau untuk pengisian kedalam jaringan system hidran. Jumlah hidran yang dibutuhkan didapat dari hasil luas perencanaan RTH dibagi $800 \mathrm{~m}^{2}$ sehingga menghasilkan 2 buah hidran. Dalam pengoperasiannya dibutuhkan air yang dapat mengoperasikan pemadam kebakaran (hidran) volume kebutuhan air pemadam kebakaran perlu diperhatikan sehingga tidak menyebabkan kelebihan air pada system tersebut untuk penentuan volume air hidran halaman digunakan kapasistas aliran 2400 liter/menit dengan 
waktu operasinal 45 menit maka kebutuhan air yang dibutuhkan yaitu 108 m3. Sedangkan bak air tidak boleh diisi dengan penuh karena hasil dari volume air yang dibutuhkan dengan menjaga factor keamanannya, konstruksi dimensi bak air kebakaran dalam perencanaan yaitu dengan Panjang $6 \mathrm{~m}$, lebar $7 \mathrm{~m}$, dan tinggi $3 \mathrm{~m}$. jadi volume total bak air yang dibutuhkan $126 \mathrm{~m}^{3}$.

\subsubsection{Desain Green RTH}

Dengan melihat penjelasan di atas dan setelah menggabungkan konsep yang ada, maka Desain Green RTH untuk menangani permasalahan kumuh yang ada dapat dilihat pada Gambar berikut.

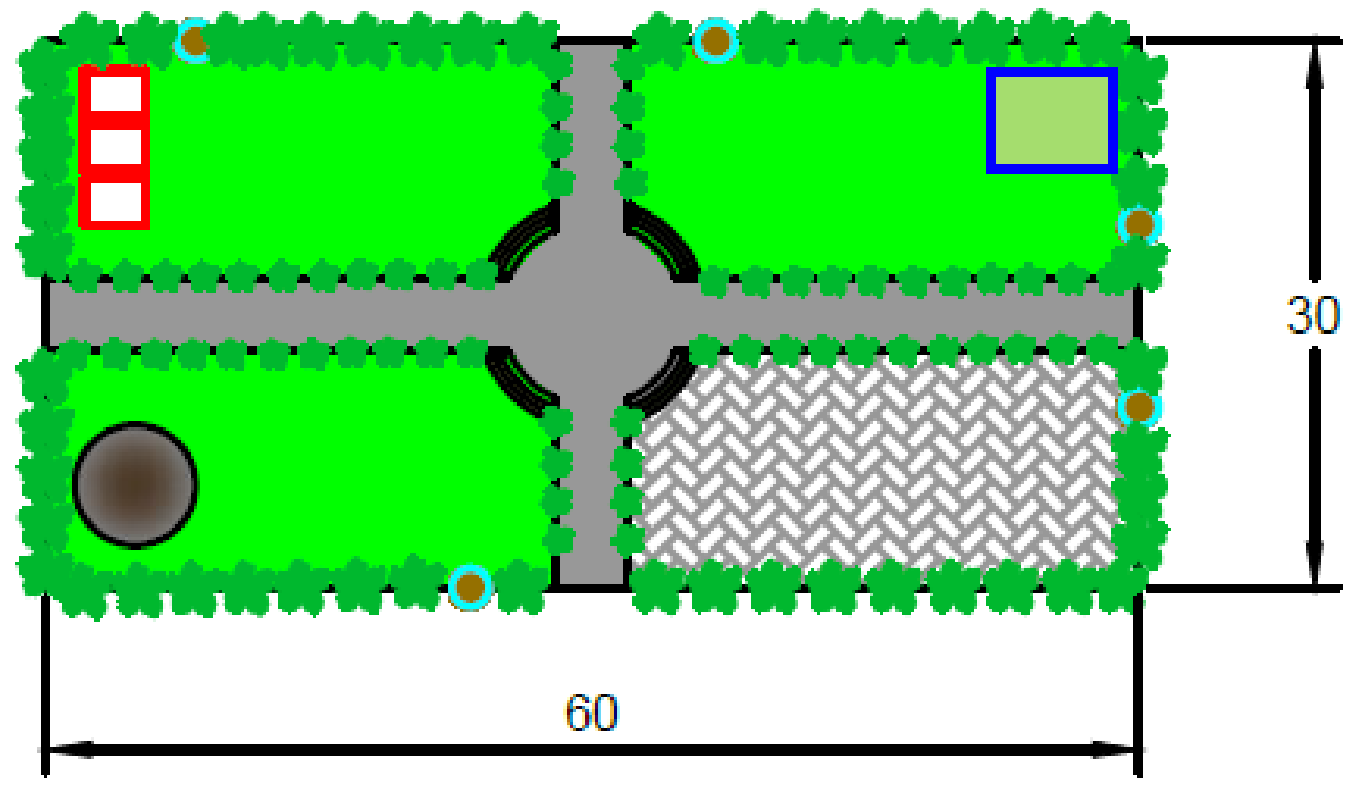

Gambar 5. Desain RTH Di Baji Dakka I, Kelurahan Mario

Dalam penerapan IPAL, komposter, sumur resapan, lubang bipori serta hidran, luas RTH yang dibutuhkan adalah $1800 \mathrm{~m}^{2}$.

\section{Target Capaian}

Kegiatan ini menargetkan pemberian informasi khususnya kepada waga di pemukiman kumuh Baji Dakka I, Kelurahan Mario, BKM Gotong Royong serta fasilitator teknik Kelurahan Mario bagaimana suatu konsep Green RTH dibuat. Dalam kegiatan ini, dihasilkan Desain yang disertai dengan dimensi dan jumlah unit yang dibutuhkan untuk melayani warga 2 RT, 1 RW. Dengan memperhatikan tingkat kekumuhan di Kelurahan Mario dan kondisi RTH yang ada, maka apabila dalam Perencannan RTH Tahun 2020 di Lokasi ini, BKM Gotong Royong dpat mengajukan untuk dibuatkan suatu RTH dengan menggunakan konsep ini.

\section{Implementasi Kegiatan}

Dalam Program pengabdian ini, sosialisasi dilakukan pada masyarakat tetang pentingnya suatu RTH pada tiap kawasan. Di kampong Mario telah memiliki suatu kelembagaan yang melaksanakan berbagai program sanitasi dari pemerintah sehingga koordinasi antara pelaksana dan mitra lebih terpadu. Sosialisasi yang dilakukan berupa penyuluhan tentang RTH dan Konsep Green RTH. Dalam sosialisasi akan dikemukakan konsep Green RTH pada lokasi RTH yang telah ditentukan. 


\section{Hasil dan Diskusi}

Proses pelaksanaan kegiatan pengabdian ini teah melibatkan masyarakat setempat, BKM Mario, fasilitator Teknik Kelurahan Mario dan Beberapa kelurahan lain dalam lingkup kecamatan Mariso. Sebanyak 25 peserta mengikuti proses pelaksanaan kegiatan.

\section{Kesimpulan}

Masyarakat, BKM dan fasilitator di Kelurahan Mario sangat antusias dalam penerimaan materi dimana dalam diskusi banyak menjelaskan bagaiman operasi IPAL dalam RTH, dan bagaimana RTH yang berkelanjutan dapat diterapkan pada wilayah lain yang memiliki permasalahan sanitasi yang sama.

\section{Ucapan Terima Kasih}

Ucapan terima kasih kepada Bapak Akhmad slaku coordinator BKM Mario, warga Jalan Baji Dakka 1 serta fasilitator kelurahan Mario. Penghargaan yang setinggi-tingginya kepada pihak Fakultas Teknik, Universitas Hasanuddin melalui hibah yang telah mampu mendukung terlaksananya kegiatan ini. Ucapan terima kasih kepada pihak Kelurahan Mario, KOTAKU Makassar yang sangat mendukung terlaksananya kegiatan ini.

\section{Daftar Pustaka}

Arafiq, Aldi Qaedi wildan. 2013. Perencanaan Dan Perhitungan Kebutuhan Lubang Resapan Biopori di Dinas Pendidikan Provinsi Jawa Barat. Bandung: perhimpunan penjelajah dan pencinta alam Bandung.

Budi. Retna Hidayah Santoso. 2012. Pola Pemanfaatan Ruang Terbuka Hijau Pada Kawasan Perkampungan Plemburan Tegal,Ngaglik Sleman. Jurnal Inersia Volume VIII Nomor 1 Mei 2012.

Darmawan. Nana Juanda Listya. 2012. Penataan Kawasan Kumuh (Pulo Geulis) Kelurahan Babakan Pasar Kecamatan Bogor Tengah Kota Bogor. Jurnal Planesa Volume 3 Nomor 1 Mei 2012.

Damanhuri, Enri. DIKTAT KULIAH TL-3104 PENGELOLAAN SAMPAH. Program

Studi Teknik Lingkungan Fakultas Teknik Sipil dan Lingkungan Institut Teknologi Bandung Edisi Semester I - 2010/2011.

Hasanah. Nurul. 2015. Konsep Pengembangan Kota Green City, Smart City, Compact City, Mega City, Kota Satelit/Baru. Surabaya: Jurusan Perencanaan Wilayah dan Kota Institut Teknologi Sepuluh Nopember.

Iriani, Kurnia Guanawan Agustin. 2013. Perencanaan Sumur Resapan Air Hujan Untuk Konservasi Air Tanah Di Daerah Permukiman. Jurnal Inersia Volume 5 Nomor 1 April 2013.

Jekson. Mononimba Windy Kotterisa. 2018. Identifikasi Tingkat Kekumuhan Kawasan Bataran Sungai Ampera Kelurahan Kaibus Kabupaten Sorong Selatan. Jurnal Spasial Volume 5 Nomor 22018 ISN 24423262.

Muhammad Al, Riki Effendi. 2017. Perancangan System Pemadam Kebakaran Pada Perkantoran Dan Pabrik Label Makanan PT XYZ Dengan Luas Bangunan 1125 M $^{2}$. Jurnal Mesin Teknologi Volume 11 Nomor 2 Desember 2017

Peraturan Menteri Pekerjaan Umum Nomor: 05/PRT/M/2008 Tentang Pedoman Penyediaan Dan Pemanfaatan Ruang Terbuka Hijau Di Kawasan 
Perkotaan.

Peraturan Republik Indonesia Undang-Undang Nomor 1 Tahun 2011 tentang Perumahan dan Kawasan Permukiman.

Peraturan Menteri Dalam Negeri Nomor 1 Tahun 2007 Tentang Penataan Ruang Terbuka Hijau Kawasan Perkotaan.

Raisya. Bitta Pigawati Nursyahbani. 2015. Kajian Karakteristik Kawasan Permukiman Kumuh di Kampung Kota. Jurnal Teknik PWK Volume 4 Nomor 2015.

Rhenny Ratnawati, Muhammad Alkholif. Desain Instalasi Pengelolahan Air Limbah (IPAL) Biofilter Untuk Mengolah Air Limbah Poliklinik UNIPA Surabaya. Jurnal Teknik Volume 12 Nomor 02 Juli 2014 ISSN : 1412-1867.

SNI 19-7029-2004. 2004. Spesifikasi Komposter Rumah Tangga Individual dan

Komunal. Jakarta: Badan Standarisasi Nasional.

SNI 3242:2008. 2008. Pengelolaan Sampah di Permukiman. Jakarta: Badan Standardisasi Nasional.

SNI No. 03-2453-2002. 2002. Tata Cara Perencanaan Sumur Resapan Air Hujan Untuk Lahan Pekarangan, Jakarta: Badan Standardisasi Nasional. 